\title{
Analysis of Kangan and Dalan Formations Lithology and Reservoirs Properties in southern Iranian gas fields
}

\author{
Davood Bargahi \\ Department of Petroleum Engineering, Kharg branch, Islamic azad university, Kharg, Iran; dbargahi@gmail.com
}

\section{Article history:}

Received date: 12 May 2020

Review date: 13 July 2020

Accepted date: 25 July 2020

\section{Keywords:}

Lithology, Geostatistics, Core Analysis, Three-Dimensional Visualization

\begin{abstract}
The results may support the geologists to recognize the type of layers, layer thickness, sedimentary structures, fractures and separation of depositional environments. Therefore, study on formation lithology makes it possible for geologists to select appropriate strategies for drilling all kinds of wells and solving Study of formation lithology in oil and gas fields plays a significant role in view of drillers and geologists. any unpredicted problems during drilling operation. This paper aims to review drilling, geological reports, logs, cores of 26 drilled wells in the field and also using geostatistical methods to build models of drilled formations structure in the first step and thenas the second step to determine types of layers, layer thickness and their geologic age.
\end{abstract}

Please cite this article as: Bargahi D.2020. Analysis of Kangan and Dalan Formations Lithology and Reservoirs Properties in southern Iranian gas fields. SRPH Journal of Fundamental Sciences and Technology, 2(3), 1-10

\section{Introduction:}

Three-dimensional visualization of geological structures makes possible to gather all available data for oil fields and consequently toanalyzethese data. There are different methods for three-dimensional modeling, in each of which geological, mathematical or statistical information is used. There are also several software for modeling various aspects of the reservoir [10]. Geostatistical methods are used to describe heterogeneity in reservoir of which the scale is smaller than the distance between the wells. At present, geostatistical method is a powerful tool in modeling. Generally, the geostatistics is the study of the phenomena changing in space or time. Variables used in geostatistics are selected randomly. A random variable is a variable in which any value in its range is similar with a certain probability; in other words, any value of it has a certain likelihood of occurring [1].

In geostatistics, variables with spatial structure are studied. First, the presence or absence of the spatial structure among the data is addressed. Then, in case of spatial structure, the analyses are performed. So, from the perspective of geostatistics, each sample has spatial relationship with the samples around it up to a certain maximum distance. This distance, also known as effective range, is very important and in fact indicates the distance in which statistical estimations can be used. According to above description, it is evident that in geostatistics, using the data of a quantity in known coordinates, the coordinates of that same quantity can be estimated in a point with other known coordinates within the domain where spatial structure is dominant [2]. 
One of the most important parameters for determination the lithology is to know the behavior of different formations in drilling. Hence, study of drilled formation lithology in oil and/or gas fields in detail, geological and petrophysical information will need which these data obtain from wire line logs, cores, cuttings and the relevant data of geology [3]. However, to recognize the main layers or types of lithology with accuracy in high level and minimum error is performed in oil industry. One of the methods which used to determine lithology is wire line logs that to record layers characteristics based on their depth. Easy description, identification and determination of formation lithology in depths are taken into account as the advantages of this method. The major parameters which gathered by log data to determine lithology includes porosity, water saturation, producing zone thickness, lithology, and etc. One of the log which can further assist in determining the lithology log includes Gamma Ray Log, Sonic Log and Neutron Log [5].

Gamma Ray log explains the natural radioactivity of rocks and help to recognize types of rocks, stratigraphy match and the presence of shale in limestone layers as well. Sonic Log is a reflection of wave velocity in rocks. Therefore, Sonic log is measured on time taken $(\Delta t)$ of compression waves per feet of the formation In general, the constant speed of sound depends on the porosity and lithology [6]. Neutrons are sent into the formation from a chemical source in logging device. when neutrons are entering into the formation strike to the core of material formation which cause to reduce neutrons energy. Since, the neutron mass is equivalent to atomic mass of hydrogen. maximum neutron energy loss is occurred while strikes with the hydrogen atom. So, the amount of porosity and lithology is obtained from Neutron log. Regarding types of receiver, distance between the receiver and transmitter and type of lithology, Neutron logs will be somehow variable [8]. An example of wire line logs interpreted in this study as shown in figure 1.

With respect to the complex lithology of drilled formation in the field, a combination of different graphs can be useful for indicating lithology which the best method is related to Cross Plot MN. Cross-plot diagram is obtained from the combination of three neutron, density, and sonic logs. In this diagram, parameter $\mathrm{M}$ indicates the extent of Density-Sonic and parameter $\mathrm{N}$ is the slop of cross-plot Neutron-Density where parameters $\mathrm{M}$ and $\mathrm{N}$ obtained according to the following relations while plotted against each other [5].A sample of cross-plot from one of the well in field is shown in figure 2.

$$
M=\frac{\Delta t_{f}-\Delta t}{\rho_{b}-\rho_{f}}
$$

Where $\Delta t_{f}, \Delta t, \rho_{f}$ and $\rho_{b}$ the time taken in solution (for drilling mud with fresh water 189 and salt water 185), obtained time by the log, specific mass of fluid or drilling mud solution (for drilling mud with fresh water equal to 1 and salt water equal to 1.1 ), and specific mass of total formation, respectively.

$N=\left[\frac{\varrho_{N F}-\varphi_{N}}{\rho_{b}-\rho_{f}}\right]$

Where $\emptyset_{N}$ and $\emptyset_{N F}$ formation porosity obtained from the neutron log, solution porosity from the neutron log, respectively. 


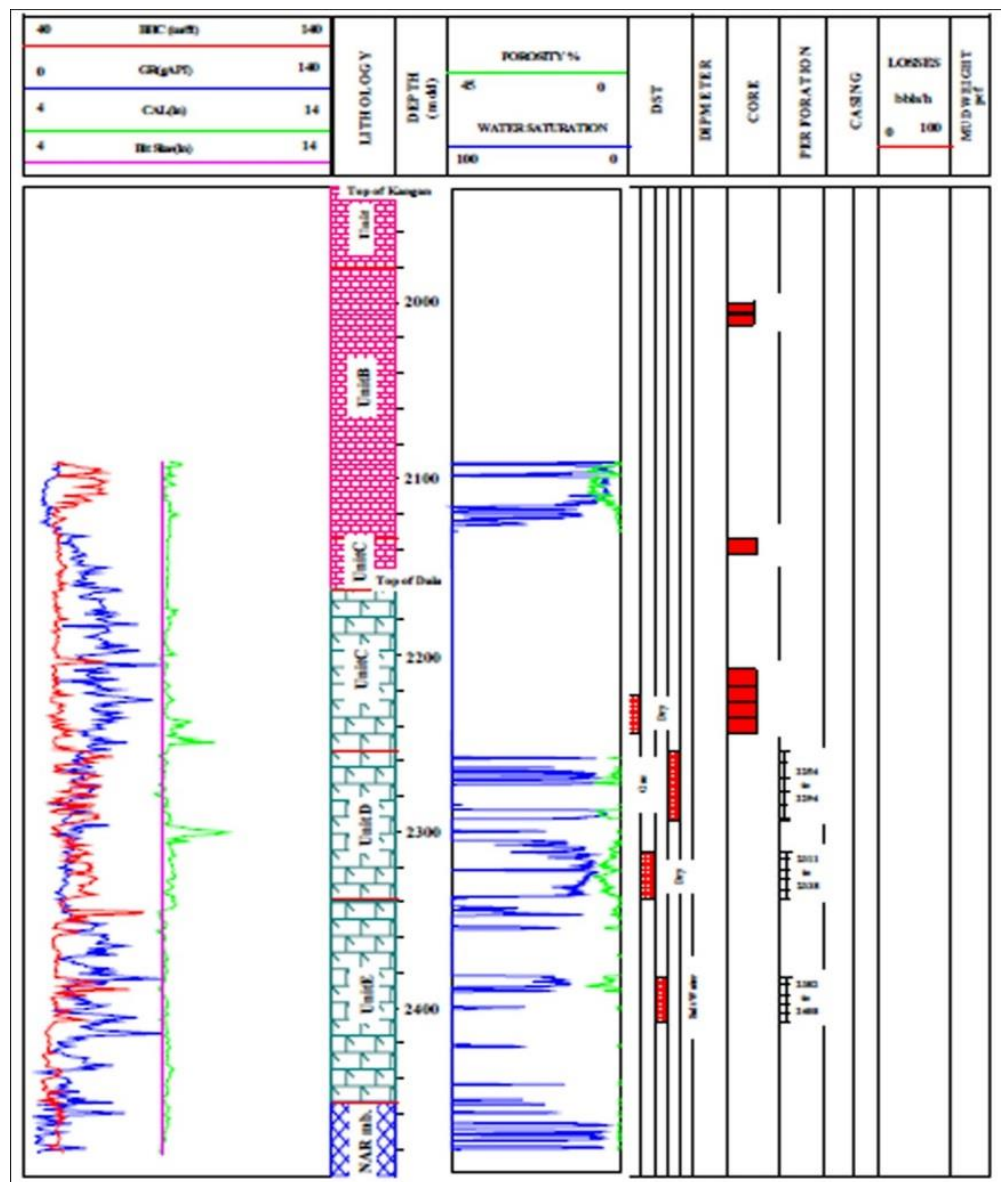

Figure 1: an example of interpreted wire line logs
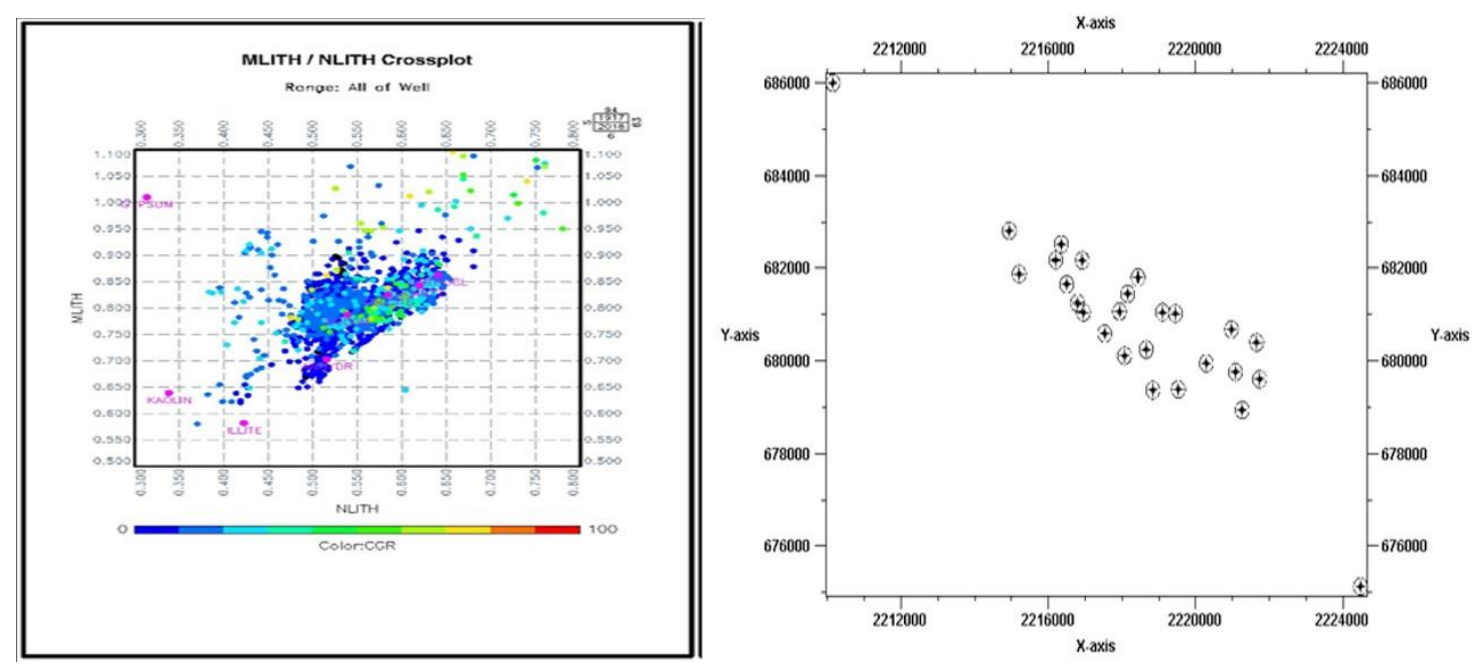

Figure 2: Cross-plate MN to determine the lithology of drilled wells in Nar field Figure 3: wells position

The best source to confirm the wire line logs results are cores. Core is defined as a cylindrical sample of rock layer which obtained during drilling period for laboratory test and etc. Core applications in oil and gas industries including full characterization of reservoir rock, determination of joints system, variations of lithology such as construction and tissue, variations of petrification, porosity and fluid properties [9]. 


\section{Field under study}

NAR gas field is located at north east of Kangan gas field and 115 Kilometers from Bushehr port. NAR field has anticlinal structure with north west-south east axis length of 28 Kilometers and varying width of 5 to 8 kilometers where the south-eastern part is wider than north-western part. Areal closure on top of Kangan formation is about 160 kilometer square, vertical closure is about 1162 meters with 983 meters of proven gas column.

\section{Methodology}

In order to review the status of wells, locations of wells in the field of study are recognized as a first step (figure 3). However, after determining the location of wells to find out three-dimensional models of field geological, the reports obtained from drilling and geological reports of 26 drilled wells in this field were analyzed and then entry point to any formation, formation thickness, position of substrate and boundary layers are characterized. Hence, to obtain the necessary information, we model the surface of upper and lower formations and three-dimensional field and formations are presented.

\section{Kangan Formation}

The Kangan Formation was named after the Kangan Village and its nearby Kangan Gas Field, located some 175 kilometers to the south of Bushehr Port. In the Kuh-e Siah type section, the Kangan Formation is selected over the interval 2691-2869 meters with a thickness of about 178 meters. In Kuh-e Surmeh surface section, the Kangan Formation thickness is only 140 meters.

Lithology: The Kangan Formation comprises of the three well recognizable rock types as follows:

1) Clean carbonate layers and beds.

2) Basal argillaceous and shale beds.

3) Clean evaporitic carbonates.

The clean carbonate beds, present in the Kuh-e Siah-1 subsurface type section, are pelletoid and oolitic grain stones and mudstones, all part to completely dolomitized with occasional anhydrite beds. Toward the bottom, this faces becomes slightly silty and/or sandy. These sequences, in the drilled section of wells, are recognizable by their low radioactivity exhibited by the Gamma Ray logs. The basal argillaceous and shale beds have limited areal extent, and in subsurface are consisted of shale, argillaceous limestone and dolomitic layers, while in surface, vermicular limestone, dark gray, soft, weathered, with lami Nar to thin layering containing pelecypods as Claraia are noticeable. The contact of the argillaceous limestone and clean carbonates are gradational. The clean evaporitic carbonates are only well represented in the Kangan formation of the Lurestan area.

In the Zagros Mountains, the Triassic sediments, due to the pre- Jurassic erosion, are very thin. In the northwestern parts of the Zagros Mountains, in the Oshtoran Kuh area, the exposed outcrops of the whole Kangan formation consists of vermicular limestone, dolomites and solution breccia. In the Persian Gulf area, the Kangan formation is in shelf limestone faces with good reservoir characteristics, having an average porosity of $20 \%$. This suitable reservoir property decreases towards land as it is about $15 \%$ in coastal Fars 
and with further deterioration decreases to 5\% in interior Fars. The Kangan Formation in nearby fields, such in Dalan, Varavi, Shannool, and exploration dry hole drilled in Dashtak is in marl facies and generally represent poor reservoir characteristics. The thickness of the Kangan Formation in the Nargas field varies from a low of 194 meters to a high of 227.5 meters (Figure 4).

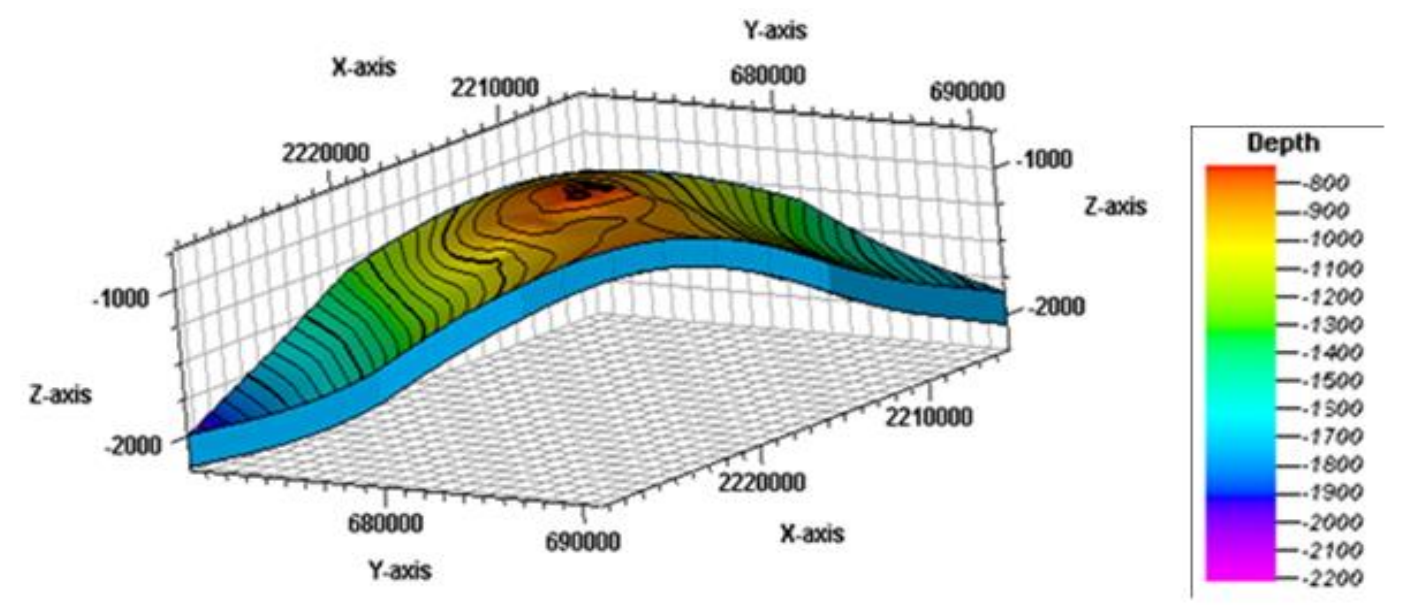

Figure 4: Kangan three-dimensional formation

Three operational units are recognized in this formation:

a) Unit "A": This is grey, microcrystalline, in parts argillaceous pellet, pseudo-oolitic dolomite (Figure 5a), rare milky anhydrites are present. Bioclastic debris is recorded in the lower part. Low intercrystalline porosity are present at higher levels, pores are frequently filled with anhydrite. The depositional environment of this unit, may be considered as intertidal probably high intertidal.

b) Unit "B": This is grey to light brown crystalline oolitic, bioclastic, anhydrite dolomite, with interbeds of red brown and green, grey shale at different levels (Figure 5b). Oolitic dolomites are abundant at certain levels (Figure 5c). Fauna are rather scarce, which includes few ostracods and gastropod debris (Figure 5d). The inter crystalline porosity is partially filled by anhydrite. The depositional environment is low intertidal.

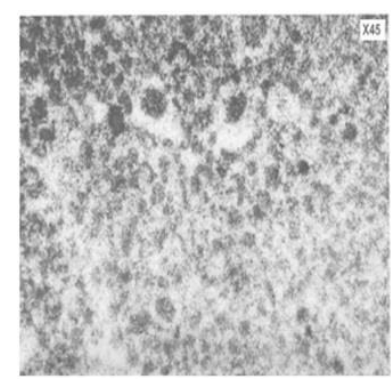

(a)

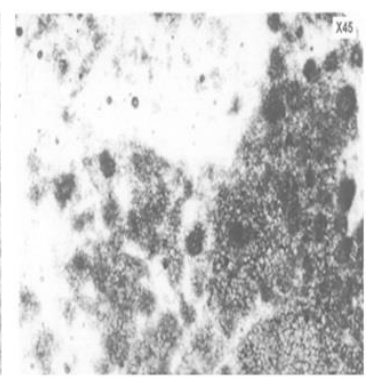

(b)

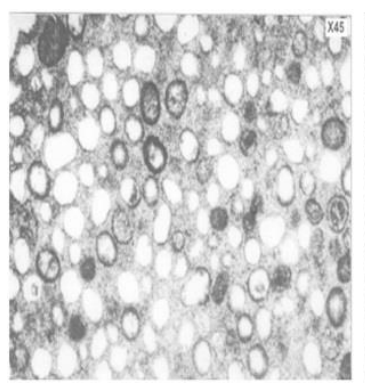

(c)

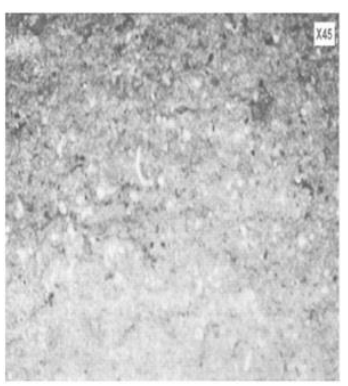

(d)

Figure 5: the samples taken from Kangan formation (a) in depth of $2136 \mathrm{~m}$. with Dolomitized and Pellety lithology (b) in depth of $2149 \mathrm{~m}$. with Pseudo-oolitic and Dolomitic lithology (c) in depth of $2157 \mathrm{~m}$. with oolitic lithology, but Oolites are filled with Dolomite crystals (d) in depth of $2202 \mathrm{~m}$. with lithology Mudstone, with small Ostracodes 
c) Unit "C": This unit is divided into two parts, and the upper part of the unit is included in Kangan Fm. It is made of grey, micritic, argillaceous, bioclastic, pellet, fossiliferous limestone. Anhydrite inclusions block a part of the porosity. The depositional environment has been considered as intertidal.

Boundaries: The contact of the Kangan Formation with the overlying Aghar shale is assumed to be conformable. The contact with the underlying Dalan Formation is unconformable, due to Perm-Triassic unconformity. There are strong stratigraphic, sediment logical and faunal evidence to differentiate it from the underlying massive carbonates of Permian age.

\section{Dalan Formation}

The name Dalan Formation has been adopted from the Dalan Gas Field located approximately 110 kilometers south-southwest of city of Shiraz, where the Dalan exploration well No.1 has penetrated a representative section of the Dalan Formation. As no typical surface exposure was known for this rock sequence, a subsurface type section from Kuh-e-Siah exploration well No.1, over the drilled interval 2869 3617 meters with a thickness of 748 meters, was selected as the type section. The only good surface exposure is present in the western plunge of Kuh-e Surmeh, 110 kilometers south-southwest of Shiraz, where only 638 meters of section is exposed.

Lithology of the Dalan Formation: the Dalan Formation consists of two major lithologies. Carbonates and evaporates. Stratigraphically, the Dalan Formation is subdivided into one formal and two informal members (shown in Figure 6) as follows:

a) Upper Carbonates (Upper Dalan): The "Upper Carbonates" or the Upper Dalan is consisted of oolitic limestone in the lower parts and micritic limestone and dolomite layers in the upper parts. A few stringers of anhydrite dolomites are also present near the top. A wide spread and easily recognizable anhydrite bed, called "Evaporate Marker C" zone is also present. The "Upper Carbonate" thickness is about 300 meters in the general area of Nar, this thickness increases in areas where the upper parts of Nar member's Evaporites laterally changes into dolomites. The base of the "Upper Dalan" is therefore a facies boundary and is selected where evaporates beds become a predominant lithology and the upper boundary is the post Permian disconformity. The upper Dalan thickness in NAR wells with full penetration is between 260 to 280 meters. These thickness variations are mostly due to the well locations, and not much could be attributed to the facies changes. The "Upper Carbonate" lithology in Nar gas field is consisted of limestone, gray to dark gray and grayish brown, bioclastic, in part pseudo-oolitic, dolomitic, pelletice, argillaceous and anhydrite (Figure 7). Considerable evidence is available to indicate that Fusulinids were uncommonly sensitive to their physical surroundings. They seem to have been restricted to off - shore, open water environments.

Three operational units are recognized in upper Carbonates:

Unit "C": The lower part of unit "C" is included in the Dalan Fm. It consists of dense limestone with thin layers, microcrystalline, argillaceous limestone with thin layers of calcareous shale and dense micritic dolomite. Foraminifera, ostracoda and algae are present (Figure 8a). The porosity is poor and linked with oolite dissolution. The depositional environment is subtidal. 


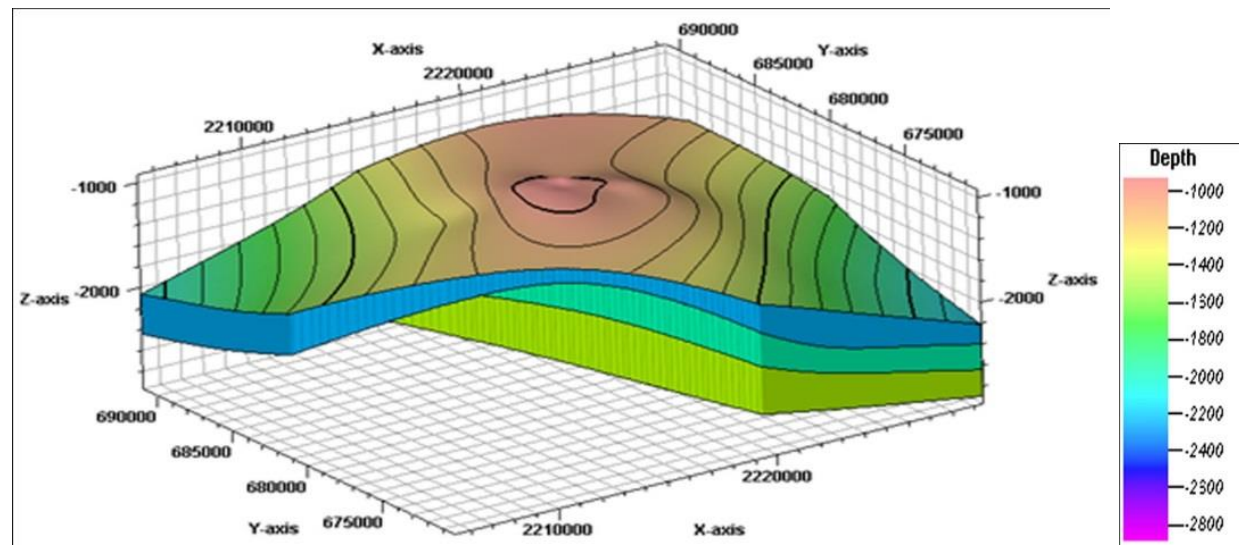

Figure 6: Dalan three-dimensional formation

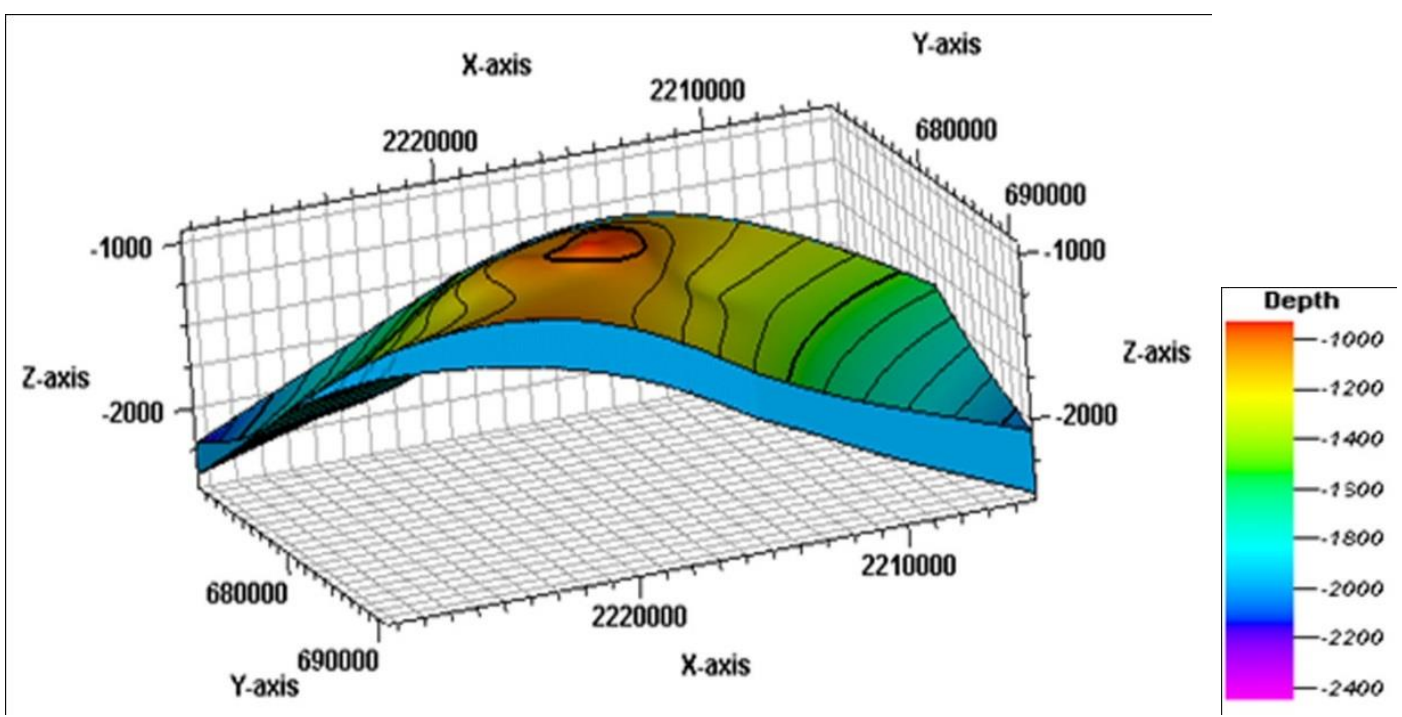

Figure 7: Upper Dalan three-dimensional formation

Unit "D": Consists of light brown, crystalline, porous, bioclastic and rarely anhydrite dolomitic limestone. It, principally, is composed of oolitic and pelletal grain stone. Foraminifera and echinoderms are present (Figure 8b). Porosity corresponds to the dissolution of oolites. The depositional environment is defined as intertidal (Figure 8c).

Unit "E": Consists of brownish grey to dark grey microcrystalline fossiliferous dolomitized limestone. Certain dolomitic oolites are present. Dolomitized foraminifera and bioclastics are present. The porosity is poor and at certain layers anhydrite inclusions fill inside the pores (Figure 8d). The depositional environment is considered as intertidal.

b) Nar Member: Massive bedded anhydrites, anhydrite dolomites and oolitic limestone are the main rock constituents of the Nar Member. The stratigraphic level of the Nar member's upper contact varies considerably in areas to the south and southwest, which is mainly due to faces change, as the anhydrite beds pass laterally to evaporitic dolomites and eventually to dolomites.

No evaporate beds are present in the surface sections of Gahkum and Faraghan areas near Bandar Abbas which probably point to presence of a more open marine environment in the region, while in the north Fars 
area, a more restricted sedimentary conditions prevailed resulting in deposition of evaporitic beds with the most massive bedded evaporates being deposited in the upper parts of the Nar member.

The Nar member thickness in the Nar wells wherever drilled, is between a maximum of 276.5 meters to 257.5 meters. This minor thickness variation could be attributed to the dip of the Nar member in the location of the wells. The lithology of the Nar member in well NAR gas field is consisted of inter beds of white anhydrites with dark gray, slightly calcareous, crystalline to microcrystalline, pseudo-oolitic, bio-clastic dolomite with anhydrite inclusions. In respect of the reservoir characteristics of the NAR Member, the anhydrite beds are generally considered as non-reservoir layers and porosity if present is associated with the interbedded oolitic dolomites (Figure 9).

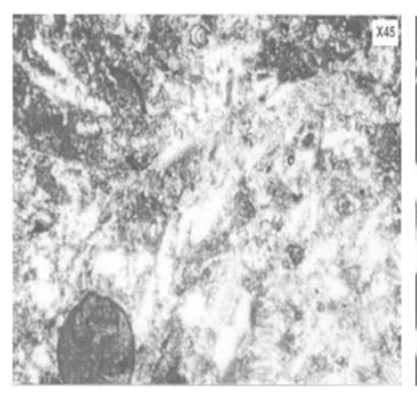

(a)

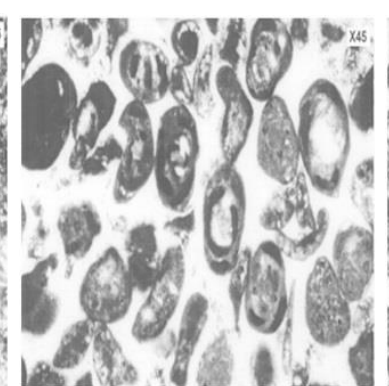

(b)

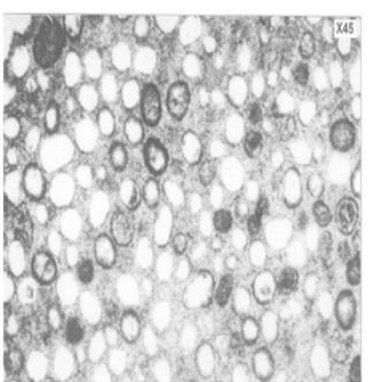

(c)
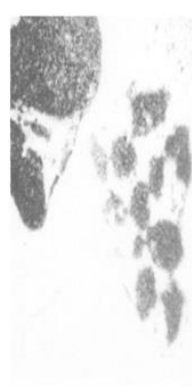

(d)

Figure 8: the samples taken from the substrate upper Dalan (a) in depth of $2319 \mathrm{~m}$. with Wackstone, algae, and foraminifera lithology (b) in depth of $2322 \mathrm{~m}$. with Packstone / Grainstone, Pseudo_Oolitic lithology (c) in depth of $2450 \mathrm{~m}$. with Oolitic facies, with Oomoldic Prosity lithology (d) in depth of $2540 \mathrm{~m}$. with Grainstone, Anhydritic lithology

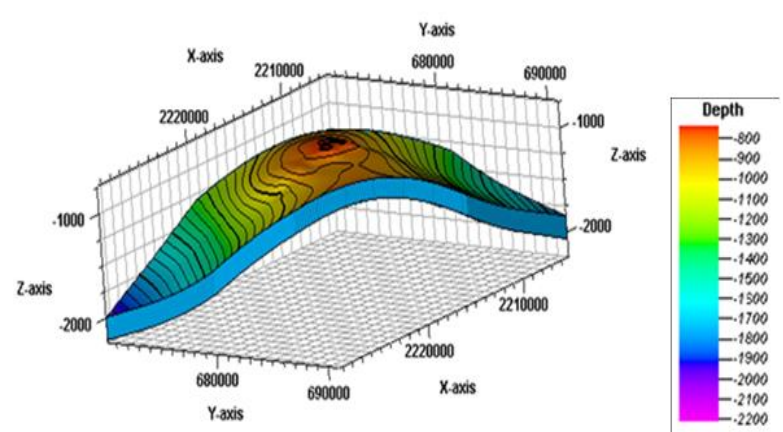

Figure 9: Nar Member

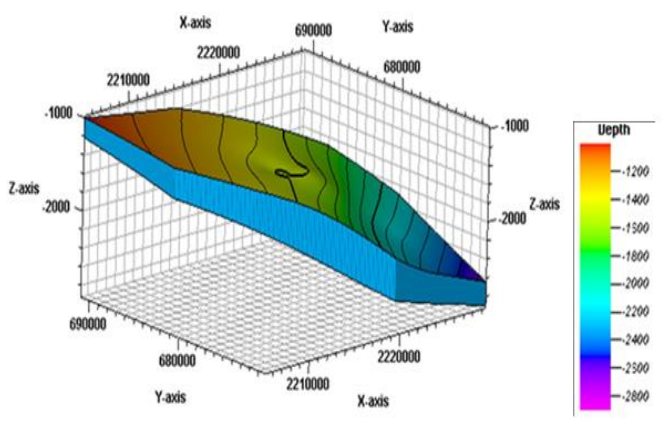

Figure 10: Substrate lower

c) Lower carbonates (Lower Dalan): The "lower Carbonates" are essentially made up of fossiliferous lime stones and dolomites in the lower parts of the section and oolitic and pelletoidal lime stones with a few beds of completely dolomitized lime stones and dolomitized oolitic limes tones in the upper parts. The lower fossiliferous zone is well recognizable in the surface outcropping sections by the presence of abundant macrofossils and in the subsurface by a relatively very clean Gamma Ray log character.

This layer is generally referred to as the basal bio-clastic limestone. Good surface exposures from this layer are present in the Kuh-e-Surmeh, Kuh-e-Gahkum and Kuh-e-Faraghan areas. This layer being the first carbonate beds, deposited from the Permian Sea, contain abundant macrofossils, such as crinoids, corals, 
bryozoan and gastropods with sand and silt grains and sandstone beds near the base. This basal bioclastic limestone is separated from the overlying carbonates (lime stones and dolomites) of the Lower Carbonates, generally by a thin argillaceous limestone and/or a shale bed. The upper parts of the "Lower Carbonates" consist of oolitic and dolomitic lime stones with occasional porosity developments.

Two evaporate beds are present within the "Lower Carbonates" in most of the sub-surface sections, designated evaporate markers "A" and " $\mathrm{B}$ ". From these markers, the lower marker the "A" evaporate bed is less widespread than the higher marker bed the "B" evaporate bed.

The "Lower Carbonate" thickness including the basal bioclastic limestone bed, in most of the wells drilled in north Fars area, is between 250 to 300 meters, but is considerably much greater in Bandar Abbas area (Figure 10).

Boundaries: The upper contact of the Dalan Formation with the overlying Kangan Fm. is marked by the Perm-Triassic unconformity. The lower contact with the Faraghan Fm. is transitional and gradational.

Age: Age of the upper layers of the Dalan Formation in the Zagros basin is assumed to be late Djulfian and as upper Djulfian is not present, then it is concluded that this formation is being laid down during late Permian, in the Congorian to Kazanian, and Panjabian stages and probably during late Djulfian.

\section{Result}

The first step to success in any field drilling operations is familiar with formations lithology. The most appropriate method for determination of formations lithology is wire line logs and cores analysis simultaneously. In addition, engineers will able to find entry point of any formation before starting drilling operations by this model, according to the formation lithology and select appropriate strategies for drilling of any new well by exact determination of type of bit, type of mud drilling and etc. We can use these models for minimizing wells cost and drilling problems.

Consequently, the exact type of formation lithology shows that Kangan and Dalan formationsin Nar fieldwith general lithology of limestone, dolomite and anhydrite which are the largest gas reservoir rocks in Persian Gulf basin.

\section{References}

[1].Corstange, R., Grunwald, S., and Lark, R. M., 2008, "Inferences from fluctuations in the Local Variogram about the assumption of stationary in the variance",Geoderma v. 143, p 123-132

[2].Todorov, J., Popov, K., Shanov, S., Boykova, A. 2002, “Geological Condition for a Correct Geostatistical Evaluation; Example from the Elatsite Copper Deposite in Bulgaria. In”, Geostatistics Rio 2000, Kluwer Academic Publishers, 177-189.

[3].Kale S., Rai C.S and Sondergeld C.H., 2010,"Petrophysical Characterization of Barnett Sale", SPE Unconventional Gas Conferences, Pittsburgh, Pennsylvania, 23-25 February SPE Paper 131770.

[4].Insalaco, E., Virgone, A. andCourme, B. et al., 2006,”Upper Dalan Member and Kangan Formation between the Zagros Mountain and offshore Fars, Iran: Depositional system", biostratigraphy and stratigraphic architecture. Geo Arabia, 11, 75-176. 
[5].Hearst, J.R., Nelson, P.H., and Pallet, F.L., 2000,”Well Logging for Physical Properties”, John Wily \& Sons Ltd,Chilchester, 483pp

[6].Bateman Richard, M., 1985, 'Open Hole Log Analysis and Formation Evaluation”, Int. Human Resource Dev. Cooperation.

[7].Coring Reports of Nar_02 and Nar_03, 1976, SofiranEgoco Company

[8].Amaefule, J.O., Altunbay, M., Tiab, D., Kersey, D.G., Keelan, D.K., 1993,"Enhanced reservoir describtion: using core and $\log$ data to identify hydraulic (flow) units and predict permeability in uncored interval/wells. SPE 26436,1-16pp.

[9].Rathmell, J.J., Tibbitts, G.A., Gremley, R.B., Warner, H.R., \& White, E.K., June 1990,"Development of a Method for Partially Uninvaded Coring in High Permeability Sandstone." presented at SPE Annual Technical Conferences, Formation Evaluation, New Orleans,SPE Paper NO. 20413.

[10].Deutch, c. v., 2002," Geostatistical Reservoir Modeling”, Oxford University Press, Oxford, P 376

[11].Tempere C., Doulcet. A., Gruneisen P., 1976,"Fracturation and Structural Core Analysis of NAR-01", Iran, EGOCO Area

[12].Gruneisen, Masse, Sehans, 1977," Dipmeter, Fracturation and Structural Core Analysis of NAR-02", SofiranEgoco Company 